DOI: https://doi.org/10.31539/joeai.v1i1.183

\title{
ANALISIS PELAKSANAAN BIMBINGAN BELAJAR DALAM MENGATASI KESULITAN BELAJAR SISWA
}

\author{
Abdul Rozak ${ }^{1,}$ Irwan Fathurrochman ${ }^{2}$, Dina Hajja Ristianti ${ }^{3}$ \\ Program Studi Bimbingan Konseling Islam, STAIN Curup ${ }^{1,3}$ \\ Program Studi Manajemen Pendidikan Islam, STAIN Curup ${ }^{2}$ \\ abdulrozak90@yahoo.co.id ${ }^{1}$
}

\begin{abstract}
ABSTRAK
Penelitian ini bertujuan untuk mengetahui gambaran perencanaan penyusunan program Bimbingan Konseling khususnya Layanan PKO dengan bidang Bimbingan Belajar dan untuk mengetahui sejauh mana pelaksanaan Bimbingan Belajar yang dilakukan guru Pembimbing dalam mengatasi Kesulitan belajar siswa di SMA Negeri Simpang Semambang. Subjek penelitian ini adalah guru Pembimbing, Kepala sekolah dan siswa. Jenis penelitian ini adalah penelitian lapangan (field research), dengan pendekatan deskriptif kualitatif. Tehnik pengumpulan data dengan cara observasi, dokumentasi, wawancara dan sebaran data KPMP. Teknik analisis data menggunakan analisis deskriptif kualitatif. Hasil penelitian dan analisis data didapat kesimpulan bahwa Program pelayanan Bimbingan dan Konseling (Bimbingan Belajar) di SMA Negeri Simpang Semambang sudah direncanakan dan dibuat sesuai dengan kebutuhan sekolah serta pedoman yang ada. Faktanya pelaksanaan bimbingan belajar di SMA Negeri Simpang Semambang terkadang tidak sepenuhnya mampu menyelesaikan setiap permasalahan kesulitan belajar siswa yang terjadi akibat dari proses layanan atau bimbingan yang dilaksanakan minim intensitas dan minim kontinuitas, bisa saja dari faktor lain yang mempengaruhinya. Layanan yang dilakukan dengan format klasikal yaitu di ruang kelas adapun materi layanan hanya berupa nasehat dan motivasi, sedangkan layanan dengan bidang bimbingan belajar masih minim dilakukan.
\end{abstract}

Kata Kunci : Pelaksanaan Program Bimbingan Belajar, Kesulitan Belajar

\begin{abstract}
This study aims to determine the description of the planning of the Counseling Guidance program especially PKO Services in the field of Guidance and to find out the extent of the implementation of Tutoring by the Supervising teacher in overcoming student learning difficulties at Simpang Semambang High School. The subjects of this study were the Supervising Teacher, Principal and students. This type of research is field research, with a qualitative descriptive approach. Data collection techniques by observation, documentation, interviews and KPMP data distribution. Data analysis techniques using qualitative descriptive analysis. The results of the research and data analysis concluded that the Guidance and Counseling service program at Simpang Semambang High School had been planned and made according to the needs of the school and the existing
\end{abstract}


guidelines. The fact is the implementation of tutoring in Simpang Semambang State High School is sometimes not fully able to solve every problem of student learning difficulties that occur as a result of the service process or guidance that is carried out with minimal intensity and minimal continuity, it could be from other factors that influence it. Services are carried out in a classical format, namely in the classroom, while service material is only in the form of advice and motivation, while services in the field of tutoring are still minimal.

\section{Keywords: Implementation of Tutoring Program, Learning Difficulty}

\section{PENDAHULUAN}

Secara umum lembaga pendidikan adalah suatu wadah bagi generasi bangsa khususnya para siswa dalam menuntut ilmu, baik ilmu tentang pengetahuan umum maupun ilmu tentang pengetahuan agama. Untuk itu, sangat dibutuhkan sekali sebuah fasilitas penunjang bagi siswa atau peserta didik dalam menimba/menuntut ilmu, agar tercipta suasana dan proses belajar yang selaras dengan tujuan pendidikan, maka pemerintah harus mampu menyediakan fasilitas pendidikan yaitu berupa sekolah-sekolah ataupun lembaga pendidikan lainnya.

Sekolah merupakan salah satu lembaga pendidikan yang berkewajiban untuk mencerdaskan kehidupan bangsa, sesuai dengan Undang Undang Republik Indonensia No 20 Tahun 2003, Pasal 1 ayat 1 tentang Sistem Pendidikan Nasional yang menyatakan bahwa," Pendidikan adalah usaha sadar dan terencana untuk mewujudkan suasana belajar dan proses pembelajaran agar peserta didik dapat secara aktif mengembangkan potensi diri. Kepribadian, akhlak mulia, serta keterampilan yang di perlukan dirinya, masyarakat, bangsa dan Negara (DEPDIKNAS, 2008).

Prayitno \& Amti mengemukakan masalah belajar adalah "bersikap dan kebiasaan buruk dalam belajar, seperti suka menunda-nunda tugas, mengulur-ulur waktu, membenci guru, tidak mau bertanya untuk hal-hal yang tidak diketahuinya, dan sebagainya" (Prayitno, et al., 2004). Faktor yang menjadi penyebab kesulitan belajarumumnya dibagi menjadi dua yaitu faktor internal dan faktor eksternal. Faktor internal adalah yang berhubungan dengan segala sesuatu yang ada pada diri siswa yang menunjang pembelajaran, seperti inteligensi, bakat, kemampuan motorik dan panca indra. Faktor eksternal adalah yang berhubungan dengan segala sesuatu yang berasal dari luar diri siswa yang mengkondisikannya dalam pembelajaran, seperti pengalaman, lingkungan sosial, metode belajar- mengajar, strategi belajar- mengajar,dan fasilitas belajar- mengajar serta tenaga pengajar.

Adapun dari kedua faktor diatas maka sangatlah perlu untuk diadakan dan dilakukan bimbingan belajar terhadap siswa baik pada siswa yang mengalami kesulitan belajar maupun siswa yang tidak mengalami kesulitan belajar, dengan tujuan meminimalisir masalah kesulitan belajar siswa. Bimbingan dan Konseling ada satu jenis layanan, yaitu layanan Penguasaan Konten (PKO) dengan Bidang 
Bimbingan Belajar yang dapat diberikan kepada setiap siswa dalam proses bimbingan dan konseling.

Komunikasi atau hubungan interpersonal merupakan hubungan dari mulut ke mulut yang terjadi dalam interaksi tatap muka dimana satu sama lainnya dapat menangkap reaksi secara verbal maupun non verbal. Hubungan interpersonal ditandai dengan adanya sikap saling menghargai, loyal dan toleran antara satu dengan yang lainnya, sikap terbuka dan adanya keakraban (Ristianti, 2017).

Bimbingan dan Konseling pola 17+ terdapat beberapa jenis layanan, namun pada penelitian ini penulis hanya memfokuskan pada satu jenislayanan yaitu Layanan Penguasaan Konten dengan BidangBimbingan Belajar.Layanan Penguasaan Konten (PKO) merupakan layanan bantuan individu ataupun kelompok untuk menguasai kemampuan atau kompetensi tertentu melalui kegiatan belajar (Prayitno, 2004). Dimana menurut Prayitno bimbingan belajar merupakan salah satu bentuk layanan bimbingan yang penting dan sangatlah perlu dilaksanakan disekolah.Pengalaman menunjukkan bahwa kegagalan-kegalan yang dialami siswa dalam belajar tidak selalu disebabkan oleh kebodohan atau rendahnya intelegensi.Sering kegagalan itu terjadi disebabkan mereka tidak mendapat layanan yang memadai (Prayitno, 2001).

Ristianti menjelaskan bahwa hubungan interpersonal merupakan hubungan dua arah, karena memungkinkan kedua belah pihak saling memberikan respon sebagai umpan balik dari pesan yang disampaikan. Respon umpan balik dapat berupa bahasa verbal maupun nonverbal. Pesan saat bimbingan hendaknya berupa ajaran atau didikan, khususnya yang berkaitan dengan penelitian mahasiswa. (Ristianti, 2017)

Erny Utari mendefinisikan bahwa diagnosis kesulitan belajar adalah suatu proses upaya untuk memahami jenis dan karakteristik serta latar belakang kesulitan-kesulitan belajar dengan menghimpun dan mempergunakan berbagai data atau informasi selengkap dan seobyektif mungkin sehingga untuk mengambil kesimpulan dan keputusan serta mencari alternatif kemungkinan pemecahannya (Utari, 2013).

Sementara itu tujuan dari Bimbingan Belajar adalah untuk mengetahui masalah-masalah kesulitan belajar yang terjadi pada siswa dan agar kita dapat membantu mengatasi masalah-masalah yang dialami, oleh siswa, supaya tujuan pendidikan diharapkan dapat tercapai.Sejalan dengan tujuan dari bimbingan belajar diatas maka terdapat sebuah lembaga pendidikan yaitu Sekolah Menengah Atas di daerah Simpang Semambang, Kecamatan Tuah Negeri, Kabupaten Musi Rawas yang dikenal dengan SMA.Negeri Simpang Semambang, Musi Rawas.

SMA Negeri Simpang semambang ini masih dijumpai permasalahan siswa yang berkaitan dengan kesulitan belajar, dimana kesulitan belajar yang dialami siswa di sekolah ini terjadi selain akibat dari faktor internal siswa itu sendiri, juga berasal dari faktor eksternal atau yang berkaitan dengan fasilitas penunjang. Di sekolah ini rata-rata siswa kelas XI IPS yang menjadi subyek penelitian 
mengalami kesulitan belajar hampir pada tiap mata pelajaran dan khususnya didominasi pelajaran Matematika. Contoh dari sisi fasilitas penunjang : untuk mata pelajaran tekhnik ilmu komputer (TIK), di sekolah ini belum memiliki laboratorium komputer yang tersedia.

Tenaga pendidik juga masih dijumpai keluhan- keluhan dari siswa tentang profesionalitas/kecakapan guru mata pelajaran baik dalam menjelaskan materi maupun metode penyampaiannya. Sehingga hal ini mempengaruhi pola pemahaman siswa, yang berakibat pada kesulitan belajar siswa itu sendiri.

Adapun jumlah siswa yang ada di SMA.Negeri Simpang semambang Musi Rawas, jumlah siswa laki - laki : 159 dan perempuan : 167 dengan total : 326. Jumlah pendidik dan tenaga kependidikan : 37. Adapun siswa yang menjadi subjek penelitian ini dibatasi hanya pada kelas XI IPS 1 dan XI IPS 2, dimana untuk kelas XI IPS 1 : Laki - laki 11, Permpuan 14, total 25 siswa. Kelas XI IPS 2 : Laki-laki 13, perempan 14, total 27 siswa. Dan total dua kelas menjadi 52 siswa.

Hasil observasi di sekolah dan wawancara dengan guru BK yaitu ibu Titin Agustin.M.Pd di SMA Negeri Simpang semambang pada tanggal, 1 November 2016. Bahwa sekitar 30\% dijumpai Siswa yang mengalami masalah kesulitan dalam hal belajar pada hampir setiap mata pelajaran, khususnya pelajaran matematika, hal ini berdampak pada menurunnya nilai siswa.Dan beliau juga menjelaskan bahwasannya rata-rata siswa tersebut mengalami kesulitan dalam hal pemahaman dari semua materi yang disampaikan oleh guru mata pelajaran (Titin Agustin 2016).

\section{METODE PENELITIAN}

Pendekatan yang digunakan dalam penelitian ini adalah penelitian lapangan (field research), dengan menggunakan pendekatan deskriftifkualitatif, dimana dalam penelitian ini prosedurnya menghasilkan data deskriptif berupa kata-kata tertulis atau lisan yang dialami oleh subjek penelitian yang diamati. Jenis penelitian kualitatif deskriptif merupakan penelitian yang dimaksudkan untuk memperoleh informasi mengenai Tentang Pelaksanaan bimbingan belajar dalam mengatasi kesulitan belajar siswa.

Penelitian ini jugamendeskripsikan berbagai hal yang berhubungan dengan data-data dan penyelenggaraan alat ungkap masalah, untuk mengetahui masalah kesulitan belajar siswa SMAN 1 Simpang Semambang Kabupaten Musi Rawas.

Pendekatan deskriptif kualitatif ini dipilih karena berbagai pertimbangan, diantaranya; Pertama masalah peneliti belum terlalu jelas adanya. Kedua untuk memahami apa yang sebenarnya terjadi. Ketiga untuk memahami interaksi social dan situasi sosial tempat penelitian dilaksanakan.

Subyek penelitian ini adalah Kepala sekolah, guru pembimbing dan guru mata pelajaran serta siswa di Sekolah Menengah Atas Negeri Simpang 
Semambang. Obyek penelitian ini adalah pelaksanaan Program Bimbingan Konseling (Layanan PKO) bidang Bimbingan Belajar dalam mengatasi kesulitan belajar siswa di Sekolah Menengah Atas Negeri Simpang Semambang.Menurut Kuntjoningrat berpendapat bahwa " populasi adalah seluruh yang menjadi obyek sesungguhnya dalam suatu penelitian." Sedangkan "populasi adalah sekelompok besar yang merupakan sasaran generalisasi (Kuntjoningrat, 2007).” Berikut ini dijabarkan rincian dan indikator penelitian :

Tabel 1

Kisi-Kisi Wawancara Analisis Pelaksanaan Bimbingan Belajar dalam Mengatasi Kesulitan Belajar Siswa

\begin{tabular}{|c|c|c|c|c|c|c|}
\hline No & $\begin{array}{c}\text { Masalah } \\
\text { Penelitian }\end{array}$ & & Indikator & Sub Indikator & Informan & Ket \\
\hline 1 & $\begin{array}{l}\text { Program } \\
\text { Bimbingan } \\
\text { Konseling di } \\
\text { SMA N } 1 \\
\text { Simpang } \\
\text { Semambang. }\end{array}$ & b) & $\begin{array}{l}\text { Apa yang } \\
\text { menjadi dasar } \\
\text { dalam } \\
\text { perencanaan } \\
\text { program? } \\
\text { Apa yang } \\
\text { menjadi } \\
\text { pertimbangan } \\
\text { dalam membuat } \\
\text { program? } \\
\text { Tujuan program } \\
?\end{array}$ & 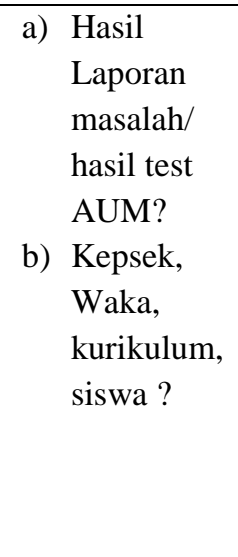 & $\begin{array}{l}\text { a) Kepala } \\
\text { sekolah. } \\
\text { b) Guru BK }\end{array}$ & \\
\hline 2 & $\begin{array}{l}\text { Pelaksanaan } \\
\text { Layanan, } \\
\text { Bidang } \\
\text { Bimbingan } \\
\text { belajar belajar }\end{array}$ & $\begin{array}{l}\text { a) } \\
\text { b) } \\
\text { c) } \\
\text { d) } \\
\text { e) } \\
\text { f) }\end{array}$ & $\begin{array}{l}\text { Jenis layanan.? } \\
\text { Tempat/waktu? } \\
\text { Pihak yang } \\
\text { dilibatkan.? } \\
\text { Media } \\
\text { layanan.? } \\
\text { Respon Siswa? } \\
\text { Faktor } \\
\text { penghambat/pe } \\
\text { ndukung dalam } \\
\text { memaksimalka } \\
\text { n } \\
\text { layanan/Bimbin } \\
\text { gan belajar. }\end{array}$ & $\begin{array}{l}\text { a) Bimbingan } \\
\text { belajar } \\
\text { b) Konseling }\end{array}$ & $\begin{array}{l}\text { a) Guru BK } \\
\text { b) Wali } \\
\text { kelas } \\
\text { c) Guru } \\
\text { Mata } \\
\text { Pelajaran } \\
\text { d) Siswa }\end{array}$ & \\
\hline
\end{tabular}

(Kuntjoningrat, 2007).

\section{HASIL DAN PEMBAHASAN}

Program

Tahapan pertama Persiapan : Study kelayakan, Penyusunan program, Konsultasi program, penyediaan sarana, koordinasi. Tahapan kedua Layanan : Layanan Orientasi, Layanan Informasi, Layanan Penempatan dan Penyaluran, 
Layanan Penguasaan Konten, Layanan Konseling Individu, Layanan Bimbingan kelompok, Layanan Konseling kelompok, Layanan Konsultasi, Layanan Mediasi. Tahapan ketiga Kegiatan pendukung : Aplikasi instrumentasi, Himpunan data Konferensi kasus, Kunjungan rumah, Alih tangan kasus.

\section{Pihak yang dilibatkan dalam pelaksaan program}

Demi terlaksana dan terwujudnya tujuan dari sebuah program maka peran pihak lain dalam realisasi program pelayanan disekolah sangatlah dibutuhkan. Untuk itu guru pembimbing melibatkan pihak yang lain, antara lain Guru mata pelajaran, Wali kelas, Orang tua dan pihak lain sesuai dengan kebutuhan.

Hasil dari realisasi ataupun pelaksanaan suatu program pelayanan bimbingan di sekolah, diharapkan mampu memberikan gambaran tingkat keberhasilan ataupun tidak dari pelaksanaan sebuah program guna proses evaluasi kedepan bagi komponen perencana program itu sendiri. Keberhasilan pelaksanaan sebuah program layanan (bimbingan belajar), dalam bimbingan dan konseling di Sekolah tidak semata didukung oleh komponen sekolah seperti keadaan dewan guru dan tata laksana serta fasilitas penunjang lainnya, akan tetapi pelaksanaan layanan tersebut akan dapat berjalan dengan baik dan berhasil apabila seluruh bagian yang masuk dalam komponen tersebut bekerjasama saling membantu sesuai dengan tupoksi dan porsi masing-masing.

Kesulitan belajar siswa yang terjadi. Hal ini terjadi, tidak hanya akibat dari proses layanan atau bimbingan yang dilaksanakan minim intensitas dan minim kontinyuitas, bisa saja dari faktor lain yang mempengaruhinya.

Faktor yang mempengaruhi permasalahan kesulitan belajar siswa tersebut bisa dari faktor external, yang terjadi, seperti : keadaan guru pembimbing/ BK, yang hanya ada satu guru saja, atau media, sarana/prasarana, dan lain sebagainya yang ada di SMAN Simpang Semambang. Dan dari hasil wawancara tidak tersruktur kepada siswa pada saat pengambilan data KPMP di ruang kelas. Menurut siswa kelas XI IPS 1, XI IPS 2, bahwa guru BK kurang maksimal dalam memberikan pelayanan /bimbingan terhadap siswa.

Untuk mengetahui sejauh mana tingkat kesulitan belajar siswa di SMAN Simpang Semambang, maka penulis memaparkan sedikit gambaran tentang kesulitan belajar yang dialami siswa. Berbicara tentang kesulitan belajar siswa berarti berbicara tentang sejauh mana seorang siswa tersebut dapat dan mampu menyerap serta menyelesaikan semua materi pelajaran dengan baik dan benar. Maka penulis mendapati kesulitan belajar yang dialami siswa SMAN Simpang Semambang cukup beragam tidak terfokus hanya pada satu mata pelajaran saja, melainkan pada beberapa mata pelajaran dengan tingkat persentasi yang berbeda.

Data hasil KPMP (Kesulitan Penguasaan Materi Pelajaran) siswa, kelas XI IPS 1 dan Kelas XI IPS 2 di SMAN Simpang Semambang, terdapat lima KPMP dengan persentase sebagai berikut : 
Tabel 2

Hasil Kesulitan Penguasaan Materi Pelajaran Siswa

\begin{tabular}{clc}
\hline No & \multicolumn{1}{c}{ Mata Pelajaran } & Persentase \\
\hline 1 & Matematika & $30 \%$ \\
\hline 2 & Bhs. Inggris & $25 \%$ \\
\hline 3 & Bhs. Arab & $20 \%$ \\
\hline 4 & Bhs. Indonesia & $10 \%$ \\
\hline 5 & Ekonomi & $15 \%$ \\
\hline
\end{tabular}

Hasil data KPMP di atas tersebut, penulis menyimpulkan bahwasannya secara umum banyak siswa baik di kelas XI IPS 1 maupun XI IPS 2, mengalami kesulitan belajar.hal ini dapat dilihat dari nilai hasil belajar dan ujian. Dimana siswa rata-rata mengalami kesulitan untuk memahami dan mengerti setiap materi khususnya materi pelajaran Matematika yang di jelaskan oleh guru, sehingga para siswa beranggapan bahwa dari kelima mata pelajaran di atas, maka matematika adalah pelajaran yang paling susah dan sulit.

\section{Analisis program Bimbingan dan Konseling}

Program Bimbingan dan Konseling SMAN Simpang Semambang, tahun pelajaran 2016/2017 disusun oleh Guru pembimbing Titin Agustin, M.Pd. Adapun uraian tugas masing-masing komponen personil pelaksana program BK di SMAN Simpang Semambang sebagai berikut :

1. Kepala sekolah. Bertugas mengkoordinasikan segenap kegiatan yang diprogramkan. Menyediakan sarana prasarana,tenaga. Melakukan pembinaan dan pengawasan terhadap perencanaan dan pelaksanaan program. Dan mempertanggung jawabkan pelaksanaan layanan Bimbingan dan Konseling di sekolah kepada Dinas Pendidikan kabupaten, kota, dan propinsi.

2. Wakil kesiswaan. Tugas membantu kepala sekolah dalam melaksanakan tugas-tugas kepala sekolah.

3. Koordinator Guru Pembimbing. Bertugas ; memasyarakatkan layanan BK, menyusun dan melaksanakan program, menyampaikan laporan BK, menganalisis data siswa, menyelenggarakan pertemuan staff $\mathrm{BK}$, evaluasi program dan lain sebagainya.

4. Guru pembimbing / konselor. Guru pembimbing / konselor sebagai pelaksana utama dari : memasyarakatkan layanan BK, perencanaan program, mengumpulkan data siswa, melaksanakan pelayanan, meneliti kemajuan dan perkembangan siswa, mengawasi kegiatan siswa, mengalih tangan kasus jika dibutuhkan, mengevaluasi proses dan hasil pelayanan BK, melaksanakan tindak lanjut dan melaporkan kegiatan pelayanan BK kepada Koordinator BK.

5. Wali kelas. Wali kelas membantu guru pembimbing / BK melaksanakan tugas khsusnya di kelas yang menjadi tanggung jawabnya, membantu guru mata 
pelajaran, membantu memberikan kesempatan dan kemudahan bagi siswa yang akan mengikuti layanan BK.

6. Guru mata pelajaran. Bertugas membantu memasyarakatkan layanan BK kepada siswa, membantu mengidentifikasi siswa yang membutuhkan layanan BK, menerima siswa raveral dari guru BK yang butuh layanan pengajaran khusus, membantu mengumpulkan informasi yang diperlukan dalam rangka evaluasi layanan BK serta upaya tindak lanjut.

Berdasarkan dari hasil penelitian serta analisis data yang dilakukan oleh penulis maka didapati bahwa ; Program pelayanan Bimbingan dan Konseling di SMAN Simpang Semambang sudah direncanakan dan dibuat sesuai dengan kebutuhan sekolah serta pedoman yang ada, dengan rincian program Tahunan, Semesteran dan Bulanan. Adapun analisis pelaksanaan bimbingan belajar Pola Relasi Bimbingan Konseling, sebagai berikut:

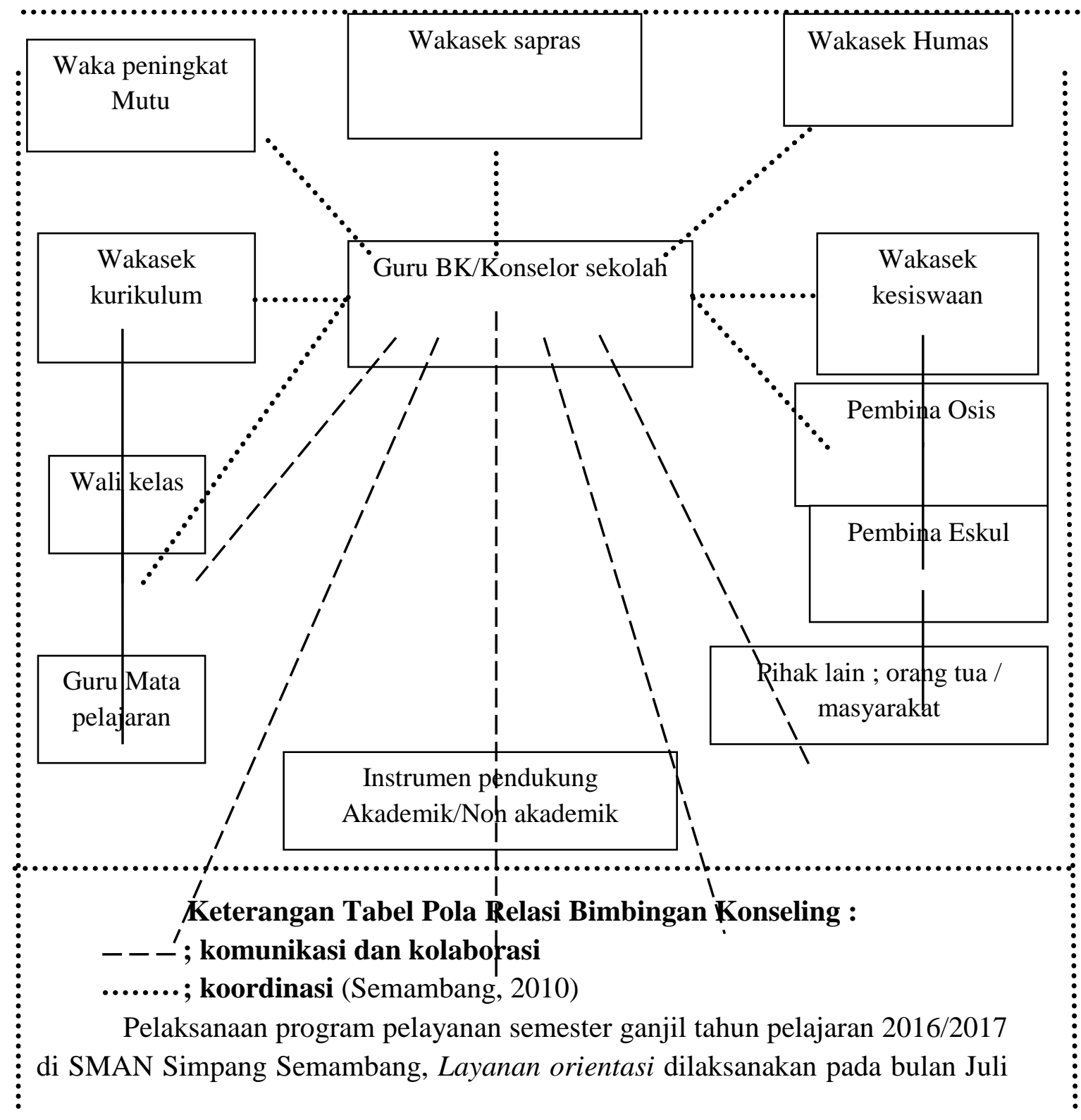


dan Agustus dengan terjadwal satu kali perbulan, dengan metode klasikal, pelaksana guru pembimbing. Layanan Informasi dilaksanakan pada bulan September dan Nopember, terjadwal dengan metode klasikal oleh guru BK (Fahruddin 2017).

Layanan penempatan dan penyaluran dilaksanakan pada bulan Agustus terjadwal satu kali,oleh guru BK. Layanan penguasaan konten (dengan bidang bimbingan belajar),dilaksanakan terjadwal satu kali pada bulan Nopember, dengan metode klasikal oleh guru BK. Layanan Bimbingan Kelompok belum terlaksana. Begitupun dengan Layanan Konseling kelompok, Konsultasi, dan Mediasi.

Berdasarkan hasil analisis data dan observasi penelitian tentang pelaksanaan program Bimbingan dan Konseling, khususnya Layanan penguasaan konten dengan bidang Bimbingan Belajar. Maka hasil analisis tentang pelaksanaan Bimbingan Belajar dalam mengatasi kesulitan belajar siswa pada mata pelajaran Matematika di SMA Negeri Simpang Semambang.

Berdasarkan dari hasil pemaparan pembahasan penelitian di atas dapat penulis simpulkan bahwa pelaksanaan program BK, sudah berjalan sesuai perencanaan walaupun belum maksimal. Adapun hal itu terjadi dikarenakan ada faktor yang mempengaruhi diantaranya; 1) kurangnya guru pembimbing, 2) intensitas layanan, 3) minat siswa akan manfaat sebuah layanan, 4) kompetensi Pendidik, dan 5) faktor lainnya.

Dengan demikian menurut penulis wajar jikalau masalah kesulitan belajar siswa di sekolah ini, agak sulit diatasi. Bahkan tingkat persentasenya pun cenderung tidak mengalami penurunan yang signifikan. Mengingat faktor yang mempengaruhinya belum bisa diminimalisir serendah mungkin.

Contoh lain dari segi tenaga pendidik juga masih dijumpai keluhankeluhan dari siswa tentang profesionalitas/kecakapan guru mata pelajaran baik dalam menjelaskan materi maupun metode penyampaiannya. Sehingga hal ini mempengaruhi pola pemahaman siswa, yang berakibat pada kesulitan belajar siswa itu sendiri.

Selain itu penulis berpendapat bahwa bimbingan belajar juga bermakna suatu proses mengembangkan sikap, kebiasaan belajar, disiplin tentang belajar, kemampuan menguasai materi serta proses orientasi belajar di sekolah sehingga peserta didik bisa terbantu dalam proses kegiatan belajar mengajar yang diinginkan serta meningkatkan hasil belajarnya. Kemudian dengan adanya Bimbingan Belajar juga dapat membantu siswa dalam mengoptimalkan serta mengembangkan potensi diri siswa baik itu bidang akademik maupun nonakademik.

Dalam kenyataan, pelaksanaan bimbingan belajar, dihadapkan pada banyak kesulitan dan hambatan. Sebagian dari hambatan itu timbul karena keadaan dunia pendidikan sekolah di Indonesia yang masih dalam taraf perkembangan ; sebagian timbul karena sikap keluarga yang mengharapkan ini 
dan itu atau kurang mendukung usaha belajar anak ; sebagian timbul karena sikap siswa dan mahasiswa sendiri yang kurang mampu mengatur dirinya sendiri ; sebagian lagi timbul karena guru kurang mampu dalam mengelolah proses belajar mengajar.

\section{SIMPULAN}

Berdasarkan hasil temuan penelitian dan analisis data tentang pelaksanaan bimbingan belajar dalam mengatasi kesulitan belajar siswa di SMA Negeri Simpang Semambang, dapat disimpulkan sebagai berikut :

Gambaran tentang program Bimbingan dan Konseling di SMA Negeri Simpang Semambang, Musi Rawas. Bahwa program pelayanan Bimbingan dan Konseling di SMAN Simpang Semambang sudah direncanakan dan dibuat sesuai dengan kebutuhan sekolah serta pedoman yang ada.

Gambaran pelaksanaan bimbingan belajar dalam mengatasi kesulitan belajar siswa pada mata pelajaran Matematika di SMA Negeri Simpang Semambang, bahwa pelaksanaan program BK, sudah berjalan sesuai perencanaan walaupun belum maksimal. Adapun hal itu terjadi dikarenakan ada faktor yang mempengaruhi diantaranya : kurangnya guru pembimbing, intensitas layanan, minat siswa akan manfaat sebuah layanan. Dengan demikian menurut penulis wajar jikalau masalah kesulitan belajar siswa di sekolah ini, agak sulit diatasi. Bahkan tingkat persentasenya pun cenderung tidak mengalami penurunan yang signifikan. Mengingat faktor yang mempengaruhinya belum bisa diminimalisir serendah mungkin.

Hasil data KPMP yang telah dipaparkan di atas, penulis menyimpulkan bahwasannya secara umum banyak siswa baik di kelas XI IPS 1 maupun XI IPS 2, mengalami kesulitan belajar.hal ini dapat dilihat dari nilai hasil belajar dan ujian. Dimana siswa rata-rata mengalami kesulitan untuk memahami dan mengerti setiap materi khususnya materi pelajaran Matematika yang di jelaskan oleh guru, sehingga para siswa beranggapan bahwa dari kelima mata pelajaran di atas, maka matematika adalah pelajaran yang paling susah dan sulit.

\section{DAFTAR PUSTAKA}

DEPDIKNAS. (2008). Undang-undang RI.No 20 Tahun 2003 tentang SISDIKNAS. Jakarta: Sinar Grafika

Fahruddin, SH. (2017). Kepala Sekolah SMAN Simpang Semambang), wawancara oleh Irwan Fathurrochman, Dina Hajja Ristianti, Abdul Rozak. Analisis Kesulitan Belajar Siswa (10 June 2017).

Kuntjoningrat. (2007). Metodelogi Penelitian Masyarakat. Jakarta: Gramedia Prayitno.( 2004). Dasar-dasar Bimbingan dan Konseling. Jakarta: Rineka Cipta .......... (2004). Seri layanan konseling L1-L9. Padang: UNPAD

Prayitno \& Amti Erman. (2001). Panduan Kegiatan Pengawasan Bimbingan dan Konseling di sekolah. Jakata : Rineka Cipta 
Ristianti \& Dina, H. (2017). Analisis Hubungan Interpersonal Mahasiswa Terhadap Dosen Dalam Proses Bimbingan Skripsi (Studi pada Mahasiswa Semester VIII Jurusan Tarbiyah STAIN Curup). ISLAMIC COUNSELING: Jurnal Bimbingan Konseling Islam, 25-40.

Semambang, TIM SMAN Simpang. (2010). Observasi Dokumen SMAN Simpang Semambang. Laporan Sekolah, Musi Rawas: SMAN Simpang Semambang.

Titin A, wawancara oleh Abdul Rozak. Hasil wawancara dan Observasi Masalah Belajar (Monday November 2016).

Utari \& Erny. (2013). Diagnosis Kesulitan Belajar Pokok Bahasan Pecahan Pada Siswa Kelas V Sekolah Dasar. Media Prestasi Jurnal Ilmiah STKIP PGRI Ngawi,1-8. 